\title{
A Experiência de Deus. A Ação Salvífica de Deus e o Agir Humano na Perspectiva de Karl Rahner
}

Orientador: Mário de França Miranda

Mestrando: Cláudia Nascimento de Oliveira

Área de Concentração: Teologia Sistemático-Pastoral

Linha de Pesquisa: Religião e Modernidade

$\mathrm{Na}$ experiência teoria e práxis se casam e vivem juntas numa unidade fundamental. A teoria não é mais abstração e ideia vazia porque ela é explicitação da práxis e comunicação dela. A práxis não é movimentação irracional mas busca e realização de sentido. É na experiência radical de sua realidade que Deus emerge na consciência do ser humano. É pela experiência de Deus buscado e encontrado no coração da experiência da realidade que esta se torna transparente e se transforma num grande sacramento comunicador de Deus. Onde os cristãos se reúnem, como seguidores de Jesus, para se dedicar à reflexão sobre suas vidas e agir em benefício de seus irmãos e irmãs, há algo infinito e inconfundivelmente de Deus na comunhão do discipulado. Sempre temos uma sensação especial da presença de Deus quando nos reunimos em nome e pela causa dos mais pobres em nossa comunidade. A solidariedade dos que se dedicam à luta pela justiça é lugar privilegiado para nossa experiência da graça divina. Onde essa solidariedade em busca de justiça é também comunhão dos que entregam suas vidas a Deus, então esse encontro de pessoas é uma verdadeira experiência do Espírito Santo. Neste tipo de solidariedade e comunidade há uma profundeza que se abre para o amor de nosso Deus. É esse amor que é a base comum entre nós.

Palavras-chave: Experiência de Deus; Amor de Deus; Seguimento de Jesus; Ação do Espírito Santo; Amor ao Próximo. 